\title{
Pelatihan Software Perkantoran Bagi Pembina Wanita Katolik Republik Indonesia
}

\author{
Elsje Kosasih*, Tanto Kurnia \\ Jurusan Akuntansi, Universitas Katolik Parahyangan, Bandung, Indonesia
}

\section{Article history}

Received: 7 Oktober 2019

Revised: 10 Oktober 2019

Accepted: 11 November 2019

*Corresponding Author:

Elsje Kosasih,

Jurusan Akuntansi,

Universitas Katolik

Parahyangan, Bandung,

Indonesia

Email:

elsje.kosasih@unpar.ac.id
Abstract: In its $18^{\text {th }}$ Congress in 2008, the Catholic Women's Association of Indonesia (WKRI), a mass organization, set a program of "increasing small business women" (PPUK) as a program to help lift women to be able to run businesses in the economic sector. Therefore, WKRI has to empower the supervisors of this PPUK to be able to assist their fostered group and to give management guidance for the participants' businesses. Current business management can be done more easily if business actors can use various office software that is easily obtained at the moment. This software is intended to make business letters, simple financial reports, attractive presentations, even flyers or other promotional media easier. The supervisors who will assist their fostered groups, will be equipped with the expertise of various office software, to later teach those who manage businesses. An interesting phenomenon that could be observed is that the supervisors involved in this PPUK program are generally more than 4050 years old, even some of them are more than 60 years old. Making modules that are easy to understand and easy to teach to participants is a must. This training was carried out in 10 meetings from May to July 2019 and was attended by more than 20 supervisors of WKRI West Java Regional Leadership Council and Bandung Branch. It gained good feedback from the participants.

Keywords: small business; women; administration; economic; skill

Abstrak: Pada tahun 2008, berdasarkan Kongres ke 18, Wanita Katolik Republik Indonesia (WKRI) yang merupakan Organisasi masyarakat menentukan program Peningkatan Perempuan Usaha Kecil (PPUK) sebagai program nasional dengan tujuan agar para perempuan Indonesia mampu melakukan usaha di bidang ekonomi. WKRI juga perlu memberdayakan Pembina PPUK, sehingga memiliki kemampuan untuk mendampingi kelompok binaan dalam membimbing pengelolaan usaha yang dimiliki oleh para peserta. Pengelolaan usaha akan mudah apabila menggunakan perangkat lunak (software) perkantoran yang Imudah diperoleh. Software ditujukan mempermudah pembuatan surat korespondensi, laporan keuangan sederhana, presentasi yang menarik, bahkan pembuatan selebaran atau media lainnya. Para Pembina dibekali dengan keahlian berbagai software untuk nantinya diajarkan kembali kepada peserta pengelola usaha. Fenomena yang menarik dari pelatihan ini para pembina dari program PPUK sebagian besar berusia di atas 50 tahun, bahkan ada yang berusia di atas 60 tahun. Dengan melihat kondisi peserta, maka pembuatan modul pelatihan yang mudah dimengerti dan mudah diajarkan merupakan keharusan. Pelatihan dilakukan selama 10 kali pertemuan setiap minggu, sejak bulan Mei-Juli 2019 diikuti oleh lebih dari 20 orang Pembina WKRI dari Dewan Pengurus Daerah dan Dewan Pengurus Cabang Jawa Barat, mendapat apresiasi dan timbal balik yang baik dari para peserta.

Kata Kunci: usaha kecil; wanita; administrasi; ekonomi; keahlian 


\section{PENDAHULUAN}

Wanita Katolik Republik Indonesia (WKRI) adalah ormas yang berbadan hukum. Didirikan pada tanggal 26 Juni 1924 di Yogyakarta. WKRI menjadi anggota World Union of Catholic Women's Organisations (WUCWO) sejak tahun 1957 (Siregar, 2009).

Pada tahun 2008 melalui Kongres ke-18 WKRI, ditetapkan suatu program kerja bagi WKRI berskala nasional untuk Peningkatan Perempuan Usaha Kecil (PPUK). (Winarno, 2010). Program Nasional artinya harus dilaksanakan seluruh jajaran organisasi secara nasional. PPUK ini sebelumnya hanya merupakan program prioritas sejak tahun 2004 (Pradipta, 2012). Program prioritas artinya program pilihan yang sesuai dengan kebutuhan daerah masing-masing. Melihat perkembangan unit usaha kecil melalui PPUK ini maka sejak 2008 menjadi program nasional bagi WKRI. Hingga tahun 2019 ini pun, program PPUK masih berjalan dan terus berkarya memberdayakan perempuan dalam mengembangkan usaha kecil.

Sebagian besar peserta mengandalkan program PPUK untuk pemodalan. PPUK sendiri memiliki berbagai syarat dan kriteria pada saat memberikan bantuan modal pada para peserta program ini (Mangu, 2019). Sementara yang dibutuhkan oleh peserta bukan saja bantuan modal namun juga pembimbingan dan pendampingan bagi para peserta dalam pengelolaan usaha (Winarno, 2010).

Menurut Bapak Ilham Akbar Habibie sebagai Presiden The International Chamber of Commerse (ICC) Indonesia, bahwa di tengah maraknya tantangan revolusi industri 4.0., pengembangan UMKM menuju revolusi 4.0 harus dilakukan secara bertahap (Aco, 2019). Di Indonesia saat ini masih banyak UMKM yang mengandalkan mekanisasi atau industri 1.0. Harus dinaikkan terlebih dahulu untuk menjadi UMKM yang menggunakan jaringan listrik atau industri berbasis 2.0., setelah itu menggunakan komputer atau industri 3.0. Barulah selanjutnya didorong untuk menggunakan teknologi internet atau industri 4.0.

Penulis dalam hal ini mewakili institusi UNPAR telah beberapa kali melakukan pengabdian kepada masyarakat bersama dengan WKRI. Sebagai contoh: pada tahun 2016 dilakukan Pelatihan Perencanaan Keuangan Keluarga bersama dengan WKRI Ranting Sarijadi Bandung. Di tahun yang sama pula, di tahun 2016 dilakukan Pelatihan Manajemen Keuangan Keluarga dan Pencatatannya bersama dengan WKRI Cabang Pandu Bandung (Elsje Kosasih, 2016). Pada tahun 2019 ini penulis melakukan pelatihan pada para Pembina WKRI DPD Jawa Barat dan DPC se-Bandung. Tujuan dari pelatihan ini adalah agar para Pembina ini dapat melakukan pendampingan dan juga pelatihan kepada para peserta PPUK dalam bidang penggunaan teknologi komputer khususnya dalam penggunaan aplikasi perangkat lunak.

Seperti dijelaskan sebelumnya bahwa agar UMKM dapat masuk dalam revolusi industri 4.0. peserta harus diajak melakukan penyesuaian setahap demi setahap. Penulis pun sudah melakukan pelatihan pencatatan keuangan secara manual di tahun 2016 , dan pada tahun 2019 ini melakukan pelatihan berbagai aplikasi perangkat lunak (software) yang digunakan di lingkungan perkantoran kepada para Pembina WKRI. Aplikasi perangkat lunak (software) perkantoran yang dimaksudkan diasumsikan terdapat pada komputer sebagai satu paket yang umum terdapat di dalam personal computer (PC). Aplikasi perangkat lunak perkantoran ini untuk membantu pembuatan surat untuk berkorespondensi, membantu para peserta dalam pencatatan keuangan sederhana, membantu dalam mempresentasikan ide atau konsep, dan juga membantu dalam mendisain brosur atau poster. 


\section{METODE}

Sasaran langsung pengabdian masyarakat ini adalah para Pembina WKRI (Para Pembina dari Dewan Pengurus Daerah Jawa Barat dan Dewan Pengurus Cabang di Bandung berjumlah 23 orang) yang akan membimbing para perempuan di wilayah mereka untuk lebih bisa mengembangkan usaha kecil yang mereka miliki. Sedangkan sasaran tidak langsungnya adalah para pengajar yang membantu proses ini, yang harus pula melakukan pembaharuan pengetahuan tentang teknologi dan perangkat lunak perkantoran yang akan mereka jelaskan pada para Pembina WKRI. Para pengajar ini adalah para dosen maupun mahasiswa civitas akademika Fakultas Ekonomi UNPAR. Adapun modul pelatihan yang direncanakan adalah sebagai berikut:

Tabel 1. Silabus awal pelatihan perangkat lunak perkantoran

\begin{tabular}{|c|c|c|c|}
\hline No. & Topik & Software & Capaian \\
\hline 1 & Pengetikan & $\begin{array}{l}\text { Mavis } \\
\text { Beacon, } \\
\text { Microsoft } \\
\text { Word }\end{array}$ & $\begin{array}{l}\text { Peserta terbiasa dengan perangkat keras komputer. Aktivitas } \\
\text { pengetikan melalui game Mavis Beacon. Perintah dasar Microsoft } \\
\text { Word meliputi pengetikan, editing, formating sederhana. }\end{array}$ \\
\hline 2 & $\begin{array}{l}\text { Pembuatan } \\
\text { surat }\end{array}$ & $\begin{array}{l}\text { Microsoft } \\
\text { Word }\end{array}$ & $\begin{array}{l}\text { Peserta merasakan adanya peningkatan kecepatan pengetikan melalui } \\
\text { game Mavis Beacon. Peserta mengetahui beberapa format penulisan } \\
\text { surat. Melakukan layout halaman dan amplop. Membuat surat formal. } \\
\text { Menggunakan fasilitas Mail Merge dan Auto Text. }\end{array}$ \\
\hline 3 & $\begin{array}{l}\text { Pengenalan } \\
\text { Excel }\end{array}$ & $\begin{array}{l}\text { Calculator, } \\
\text { Microsoft } \\
\text { Excel }\end{array}$ & $\begin{array}{l}\text { Capaian: Peserta mengetahui adanya fasilitas untuk menghitung di } \\
\text { komputer. Peserta dapat membedakan perhitungan menggunakan } \\
\text { calculator versus microsoft excel. Peserta dapat membuat perhitungan } \\
\text { tabel dengan rumus cell absolut. Peserta dapat melakukan formating } \\
\text { cell. Pembuatan grafik. }\end{array}$ \\
\hline 4 & $\begin{array}{l}\text { Rumus dasar } \\
\text { Excel }\end{array}$ & $\begin{array}{l}\text { Microsoft } \\
\text { Excel }\end{array}$ & $\begin{array}{l}\text { Peserta dapat menggunakan rumus dasar excel untuk cell maupun } \\
\text { range. Rumus yang diajarkan meliputi; rumus waktu, rumus } \\
\text { pembulatan, rumus logika, rumus pengambilan karakter, dan rumus } \\
\text { aggregasi (range). }\end{array}$ \\
\hline 5 & $\begin{array}{l}\text { Kondisi } \\
\text { bersyarat }\end{array}$ & $\begin{array}{l}\text { Microsoft } \\
\text { Excel }\end{array}$ & $\begin{array}{l}\text { peserta dapat menggunakan rumus if untuk mempermudah pekerjaan } \\
\text { mereka. }\end{array}$ \\
\hline 6 & Pencarian data & $\begin{array}{l}\text { Microsoft } \\
\text { Excel }\end{array}$ & $\begin{array}{l}\text { peserta dapat menggunakan rumus lookup untuk mempermudah } \\
\text { pekerjaan mereka. }\end{array}$ \\
\hline 7 & $\begin{array}{l}\text { Pembuatan } \\
\text { tabel }\end{array}$ & $\begin{array}{l}\text { Microsoft } \\
\text { Excel, } \\
\text { Microsoft } \\
\text { Word }\end{array}$ & $\begin{array}{l}\text { peserta menyadari bahwa surat formal terkadang membutuhkan } \\
\text { lampiran. Lampiran dapat berupa tabel sederhana, tabel perhitungan, } \\
\text { maupun grafik. Peserta dapat membedakan penggunaan ms. word } \\
\text { versus ms.excel untuk pembuatan tabel. Peserta dapat membuat } \\
\text { header/footer dan penomoran halaman. }\end{array}$ \\
\hline 8 & $\begin{array}{l}\text { Pembuatan } \\
\text { proposal }\end{array}$ & $\begin{array}{l}\text { Microsoft } \\
\text { Word }\end{array}$ & $\begin{array}{l}\text { Peserta dapat membuat proposal dengan format formal. Peserta dapat } \\
\text { menggunakan fasilitas style dalam Ms. Word. Peserta dapat } \\
\text { menambahkan dan memformat gambar. Peserta dapat membuat daftar } \\
\text { isi. }\end{array}$ \\
\hline 9 & Presentasi & $\begin{array}{l}\text { Microsoft } \\
\text { Power Point }\end{array}$ & $\begin{array}{l}\text { Peserta dapat mengetahui hal penting dalam presentasi. Peserta dapat } \\
\text { membuat presentasi proposal dengan efektif. Peserta dapat } \\
\text { menggunakan fasilitas dasar power point. }\end{array}$ \\
\hline 10 & $\begin{array}{l}\text { Pembuatan } \\
\text { Poster }\end{array}$ & $\begin{array}{l}\text { Microsoft } \\
\text { Power Point }\end{array}$ & $\begin{array}{l}\text { Peserta dapat mengetahui pentingnya pembuatan media poster untuk } \\
\text { sosialisasi informasi. Peserta dapat membuat poster yang efektif. } \\
\text { Peserta dapat membuat poster pengumuman menggunakan Microsoft } \\
\text { Power Point. }\end{array}$ \\
\hline
\end{tabular}

Guna memastikan bahwa langkah pembimbingan dan penyusunan materi pelatihan sesuai dengan apa yang diperlukan oleh mitra dan sesuai dengan kemampuan mitra, maka penulis terlebih 
dahulu melakukan wawancara dengan mitra untuk mengetahui secara jelas dan rinci kebutuhan mereka. Wawancara dengan mitra juga ditujukan untuk mendapatkan gambaran keahlian penggunaan aplikasi perangkat lunak komputer yang dimiliki mitra pada umumnya, hal ini bermanfaat dalam menentukan program pelatihan yang perlu diberikan secara spesifik sesuai dengan kebutuhan dan kemampuan dasar dari mitra.

Setelah proses pengumpulan informasi, maka penulis melakukan penyusunan modul pelatihan yang disesuaikan dengan kebutuhan dan kemampuan mitra. Pembimbingan dan latihan sesuai dengan kecepatan masing-masing peserta menjadi cara pelaksanaan pembelajaran yang bertujuan memastikan setiap materi dapat diterima dengan baik dan mempengaruhi kelulusan peserta. Tidak seperti pelatihan yang bersifat massal, yang mengikuti kecepatan pengajar, pelatihan yang dilakukan penulis ini lebih berfokus pada kecepatan dan keaktifan setiap peserta, namun tetap menjaga tujuan bersama. Pelatih akan menangani 2 orang peserta agar memastikan proses belajar berlangsung dengan baik, sehingga jumlah pelatih yang dibutuhkan sejumlah 12 orang.

Jumlah peserta yang lulus dan kuesioner akhir tentang kepuasan peserta, adalah cara penulis dapat melakukan evaluasi terhadap pelaksanaan pelatihan. Kriteria lulus adalah jumlah minimal kehadiran 7 dari 10 pertemuan yang direncanakan dan dapat mengisi buku modul pelatihan masingmasing. Sedangkan kepuasan peserta meliputi penilaian terhadap materi yang diberikan, kemampuan pengajar, fasilitas yang ada, dan suasana pembelajaran.

\section{HASIL DAN PEMBAHASAN}

Penulis memperoleh berbagai informasi melalui wawancara pendahuluan dengan mitra. Penulis dapat mendefiniskan bahwa mitra (peserta PPUK) adalah para perempuan yang sebagian besar adalah ibu-ibu rumah tangga yang terbiasa dengan teknologi informasi smartphone, namun tidak terbiasa dengan penggunaan aplikasi perangkat lunak (software) komputer untuk mendukung kegiatan usaha atau bisnisnya. Sedangkan para Pembina (juga merupakan mitra) adalah perempuan yang sebagian besar berusia diatas 40-50 tahun yang tidak terbiasa pula menggunakan aplikasi perangkat lunak komputer yang disebutkan, karena perbedaan versi atau perbedaan jenis perangkat lunak untuk mendukung kegiatan atau pekerjaan di organisasi. Mitra dan para Pembina memiliki pengetahuan yang terbatas untuk membuat alat peraga yang membantu presentasi atau penyampaian informasi pada masyarakat. Contoh: spanduk, poster, brosur dan flyer. Selain itu untuk menunjang pengelolaan UMKM, mitra masih melakukan pencatatan keuangan dan laporan keuangan menggunakan media pencatatan manual dan belum menggunakan teknologi informasi komputer.

Penulis melalui hasil wawancara dengan mitra, juga mendapatkan kesimpulan bahwa, para Pembina akan diajarkan terlebih dahulu untuk dapat mengajarkan pada mitra usaha PPUK. Sehingga fungsi Pembina sebagai teladan juga tetap dapat dipertahankan. Para peserta pelatihan (dalam hal ini adalah para Pembina dari WKRI) diajarkan mengenal aplikasi perangkat lunak komputer dengan cara yang menyenangkan dan sesuai dengan kasus yang dialami di organisasi. Modul pelatihan dibuat fleksibel mengikuti kecepatan pembelajaran para peserta pelatihan. Setidaknya dibutuhkan 1 pendamping pelatih untuk mendampingi 2 orang peserta pelatihan untuk memastikan bahwa setiap peserta dapat mengerjakan latihannya secara aktif dan mandiri. Pendampingan ini ditujukan pula agar terdapat ikatan emosi antara peserta dan pembimbing yang dapat menambah motivasi peserta untuk dapat tetap hadir setiap pertemuan.

Evaluasi hasil pelaksanaan adalah sebagai berikut, jumlah Peserta (Para Pembina dari DPD Jawa Barat dan DPC di Bandung) adalah 23 orang, yang memenuhi kriteria lulus 21 orang. Kriteria 
lulus adalah jumlah minimal kehadiran dan dapat mengisi buku modul pelatihan masing-masing. Dalam rangka memastikan kelulusan peserta, maka pembimbing yang merupakan dosen dan mahasiswa, diperlukan pelatih dan pendamping pelatihan sebanyak 12 orang.

Realisasi pertemuan berbeda dengan rencana awal karena pertimbangan kecepatan pengerjaan latihan para peserta. adalah sebagai berikut:

Tabel 2. Realisasi pelatihan perangkat lunak perkantoran

\begin{tabular}{|c|c|c|c|}
\hline No. & Topik & Software & Capaian \\
\hline 1 & Pengetikan & $\begin{array}{l}\text { Mavis } \\
\text { Beacon, } \\
\text { Microsoft } \\
\text { Word }\end{array}$ & $\begin{array}{l}\text { Peserta terbiasa dengan perangkat keras komputer. Aktivitas } \\
\text { pengetikan melalui game Mavis Beacon. Perintah dasar Microsoft } \\
\text { Word meliputi open, save, pengetikan, editing, formating sederhana. }\end{array}$ \\
\hline $\begin{array}{l}2 \\
3 \\
4\end{array}$ & $\begin{array}{l}\text { Pembuatan } \\
\text { surat }\end{array}$ & $\begin{array}{l}\text { Microsoft } \\
\text { Word }\end{array}$ & $\begin{array}{l}\text { Peserta merasakan adanya peningkatan kecepatan pengetikan melalui } \\
\text { game Mavis Beacon. Peserta mengetahui beberapa format penulisan } \\
\text { surat. Melakukan layout halaman dan amplop. Membuat surat formal. } \\
\text { Menggunakan fasilitas Mail Merge dan Auto Text. }\end{array}$ \\
\hline $\begin{array}{l}5, \\
6\end{array}$ & $\begin{array}{l}\text { Rumus dasar } \\
\text { Excel }\end{array}$ & $\begin{array}{l}\text { Microsoft } \\
\text { Excel }\end{array}$ & $\begin{array}{l}\text { Peserta dapat menggunakan rumus dasar excel untuk cell maupun } \\
\text { range. Rumus yang diajarkan meliputi; rumus waktu, rumus } \\
\text { pembulatan, rumus logika, rumus pengambilan karakter, dan rumus } \\
\text { aggregasi (range). }\end{array}$ \\
\hline 7 & $\begin{array}{l}\text { Pembuatan } \\
\text { grafik, } \\
\text { dan table }\end{array}$ & $\begin{array}{l}\text { Microsoft } \\
\text { Excel }\end{array}$ & $\begin{array}{l}\text { eserta menyadari bahwa surat formal terkadang membutuhkan } \\
\text { mpiran. Peserta dapat berupa tabel sederhana, tabel perhitungan, } \\
\text { laupun grafik. }\end{array}$ \\
\hline 8 & $\begin{array}{l}\text { Kondisi } \\
\text { bersyarat, } \\
\text { Pencarian data }\end{array}$ & $\begin{array}{l}\text { Micrc } \\
\text { Excel }\end{array}$ & $\begin{array}{l}\text { eserta dapat menggunakan rumus if sederhana dan lookup untuk } \\
\text { nempermudah pekerjaan mereka. }\end{array}$ \\
\hline 9 & Presentasi & $\begin{array}{l}\text { Micrc } \\
\text { Powe }\end{array}$ & $\begin{array}{l}\text { Peserta dapat mengetahui hal penting dalam presentasi. Peserta dapat } \\
\text { membuat presentasi proposal dengan efektif. Peserta dapat } \\
\text { menggunakan fasilitas dasar power point. }\end{array}$ \\
\hline 10 & $\begin{array}{l}\text { Pembuatan } \\
\text { Poster }\end{array}$ & $\begin{array}{l}\text { Microsoft } \\
\text { Power Point }\end{array}$ & $\begin{array}{l}\text { Peserta dapat mengetahui pentingnya pembuatan media poster untuk } \\
\text { sosialisasi informasi. Peserta dapat membuat poster yang efektif. } \\
\text { Peserta dapat membuat poster pengumuman menggunakan Microsoft } \\
\text { Power Point. }\end{array}$ \\
\hline
\end{tabular}

Tabel 2, di atas menunjukan bahwa terdapat beberapa materi yang tidak dapat disampaikan sesuai silabus awal di kelas. Untuk materi dan latihan yang tidak dapat dilakukan di kelas, maka peserta diwajibkan mengerjakan sendiri latihannya mengikuti langkah-langkah yang ada di modul. Fleksibilitas modul menyebabkan munculnya kesulitan untuk mempertahankan topik yang dibahas di kelas. Namun dengan adanya pendamping pelatih perbedaan kecepatan peserta dalam mengerjakan latihan dapat diminimasi. Beberapa peserta bahkan bersedia untuk hadir 1 jam sebelum acara untuk mengejar ketertinggalan pengerjaan latihan. Dalam hal ini semangat belajar dari para peserta ini sangat layak untuk diapresiasi. Usia tidak menjadi halangan untuk para peserta tetap semangat belajar. Beberapa peserta membutuhkan fasilitas untuk membesarkan tulisan di layar monitor agar dapat lebih terbaca.

Hasil evaluasi kepuasan peserta, menggunakan media Mentimeter, (18 orang yang hadir di pertemuan terakhir) adalah sebagai berikut:

1. Lebih dari $70 \%$ peserta menyatakan keempat materi; Mavis Beacon, MS Word, MS Excel, dan MS Powerpoint bermanfaat 
2. Lebih dari $85 \%$ peserta menyatakan terbantu oleh para pengajar dan asisten pengajar dalam proses belajar

3. Lebih dari $80 \%$ peserta memberikan nilai positif untuk suasana belajar di kelas dan fasilitas belajar

4. Komentar terbanyak selama proses pembelajaran adalah: menyenangkan.

Masukan dari peserta meliputi, waktu belajar 10 pertemuan terlalu singkat, dan mengharapkan untuk adanya pelatihan berikutnya.

\section{KESIMPULAN DAN SARAN}

Penulis berdasarkan hasil observasi dan penilaian/evaluasi mitra dapat menyimpulkan bahwa, di tengah maraknya jargon revolusi industri 4.0, Mitra yang merupakan perempuan yang tergabung dalam Program Peningkatan Perempuan Usaha Kecil (PPUK) yang digagas oleh Wanita Katolik Republik Indonesia (WKRI) perlu dipersiapkan secara bertahap. Tahapan awal dimulai dengan pemahaman dan penggunaan cara manual dan sederhana yang dapat dimengerti dengan menyeluruh oleh mitra lalu bertahap hingga penggunaan teknologi terkini. Para Pembina yang merupakan rekan dan mentor terdekat dari mitra perlu dibekali untuk mendampingi para peserta PPUK.

Upaya pembekalan para Pembina ini mendorong penulis untuk mengadakan pelatihan penggunaan perangkat lunak perkantoran. Pemilihan materi dan cara pelatihan pembekalan dilakukan melalui beberapa tahap, diawali dengan wawancara untuk mencari kebutuhan mitra. Peserta pelatihan melalui kuesioner akhir merasa pelatihan ini sudah tepat, dan bermanfaat. Peserta pelatihan merasa perlu pelatihan lanjutan agar dapat merasa lebih yakin untuk membina peserta PPUK.

\section{Ucapan Terima Kasih}

Pengabdian kepada masyarakat ini terlaksana berkat peran serta aktif dari organisasi Wanita Katolik Republik Indonesia (WKRI) Dewan Pengurus Daerah (DPD) Jawa Barat dan Dewan Pengurus Cabang (DPC) di Bandung. Terima kasih juga kami ucapkan kepada Lembaga Penelitian dan Pengabdian Kepada Masyarakat (LPPM) Universitas Katolik Parahyangan (UNPAR), juga kepada semua pihak yang sudah membantu kelancaran pelaksanaan pengabdian kepada masyarakat ini.

\section{DAFTAR PUSTAKA}

Aco, H. (2019). UMKM Jadi Tantangan Bagi Indonesia dalam Revolusi Industri 4.0. Retrieved September 05, 2019, from tribunnews.com/bisnis: https://www.tribunnews.com/bisnis/2019/03/13/umkm-jadi-tantangan-bagi-indonesia-dalamrevolusi-industri-40

Elsje Kosasih, A. L. (2016). Pelatihan penyusunan laporan keuangan sederhana untuk usaha kecil menengah. Repository Universitas Katolik Parahyangan.

Mangu, K. R. (2019). RESTITUTI ENDANG : MODAL UNTUK PEREMPUAN. Retrieved September 5, 2019, from hidupkatolik.com: https://www.hidupkatolik.com/2019/06/12/37173/restitutiendang-modal-untuk-perempuan/

Pradipta, H. D. (2012). Penghargaan PPUK untuk Para Pejuang. Kontak Edisi No.15/Tahun IV.

Siregar, N. (2009). Organisasi. Retrieved September 05, 2019, from wkriungaran.wordpress.com: https://wkriungaran.wordpress.com/organisasi/

Winarno, N. (2010). Program Peningkatan Perempuan Usaha Kecil. Kontak Edisi No.5/Tahun II. 